\title{
Gene expression of vascular endothelial growth factor A and hypoxic adaptation in Tibetan pig
}

\author{
Bo Zhang ${ }^{1}$, Yangzong Qiangba ${ }^{2}$, Peng Shang ${ }^{1,2}$, Yunfeng $L^{3}$, Yuzeng Yang ${ }^{4}$, Zhixiu Wang ${ }^{1}$ and Hao Zhang ${ }^{1 *}$
}

\begin{abstract}
Background: Vascular endothelial growth factor A (VEGFA) can induce endothelial cell proliferation, promote cell migration, and inhibit apoptosis. These processes play key roles in physiological blood vessel formation and pathological angiogenesis.

Methods: In this study, we examined VEGFA gene expression in the heart, liver, and kidney of Tibetan pigs (TP), Yorkshire pigs that migrated to high altitudes $(\mathrm{YH})$, and Yorkshire pigs that lived at low altitudes (YL). We used PCR and Sanger sequencing to screen for single nucleotide polymorphisms (SNPs) in 5'-flanking DNA and exons of the VEGFA gene. Quantitative real-time PCR and western blots were used to measure expression levels and PCR products were sequenced.

Results: Results showed that the VEGFA mRNA and protein expression in heart, liver and kidney of TP was higher than that in $\mathrm{YH}$ and $\mathrm{YL}$. In addition, the mRNA sequence of the pig VEGFA gene was conserved among pig breeds, and only five SNPs were found in the 5'-flanking region of the VEGFA gene, the allele frequency distributions of the 5 SNPs were not significantly different between the TP, Yorkshire (YL), and Diannan small-ear (DN) pig populations.
\end{abstract}

Conclusion: In conclusion, the Tibetan pig showed high levels of VEGFA gene expression in several hypoxic tissues, which suggests that the VEGFA gene may play a major functional role in hypoxic adaptation.

Keywords: Gene expression, Hypoxic adaptation, Tibetan pig, VEGFA gene

\section{Background}

$V E G F A$ (also known as $V E G F$ ) is a major growth factor for endothelial cells. It promotes vascular permeability and angiogenesis by stimulating proliferation, migration, and survival of endothelial cells, as well as inhibiting apoptosis [1-3]. VEGFA ligand binding to VEGFRs upregulates expression of endothelial nitric oxide synthase $(e N O S)$ and increases prostacyclin production in endothelial cells [4], and is strongly expressed in antiproliferative lesions from patients with severe primary idiopathic and secondary forms of pulmonary hypertension $[5,6]$. In pig, the VEGFA gene maps to

\footnotetext{
* Correspondence: zhanghao827@163.com

${ }^{1}$ National Engineering Laboratory for Animal Breeding, China Agricultural

University, Beijing 100193, People's Republic of China

Full list of author information is available at the end of the article
}

chromosome seven, comprises seven exons, and has one transcript.

Tibetan pig (TP) is indigenous to China and live primarily in semi-agricultural and semi-pastoral areas (average elevation: 2500-4300 m) in the Qinghai-Tibet Plateau of southwest China. The TP have adapted to harsh conditions such as hypoxia [7-9], which makes this species a good model for investigating molecular mechanisms of hypoxic adaptation.

Hypoxia is a potent inducer of VEGFA through regulation of hypoxia-inducible factors (HIFs). However, the function and mechanism for hypoxic adaptation in TP remain unclear. The objective of the present study was to detect expression of the VEGFA gene in different tissues including the heart, liver, and kidney from three groups of pigs living at different altitudes. This study 
should help elucidate the function of the VEGFA gene in hypoxic adaptation of Tibetan pig.

\section{Methods}

The experimental processes were approved by the animal welfare committee of the State Key Laboratory for Agro-biotechnology of China Agricultural University (Approval number XK257), and pig farming at Linzhi of Tibet is permitted and the field study does not involve endangered or protected species.

\section{Experimental materials}

Experiments were performed using pigs from three different populations: Tibetan pig from highlands (Linzhi, 3,000 m) (TP), Yorkshire pig that migrated to high altitude (Linzhi, 3,000 m) $(\mathrm{YH})$, and Yorkshire pig raised at lowland (Beijing, $100 \mathrm{~m}$ ) (YL). Animals in the $\mathrm{YH}$ group were descended from a population of Yorkshire pigs that migrated from lowland to highland approximately 3 yr ago. Ten castrated boars from each population were slaughtered when they were 6 mo of age. Tissue samples were collected from the liver, heart, and kidney and were immediately frozen in liquid nitrogen. Samples were then stored at $-80^{\circ} \mathrm{C}$.

Ear tissue samples were collected from three pig populations: YL from the Beijing Shunxinlong Farm $(n=30)$, TP from Linzhi, Tibet of China $(n=60)$, and Diannan small-ear (DN) from Xishuang Banna, Yunnan of China $(n=40)$. The samples were immediately frozen and stored at $-20{ }^{\circ} \mathrm{C}$.

DNA, RNA, and protein extraction and CDNA preparation Genomic DNA was isolated from ear tissue as previously described [10], dissolved in TE solution, and stored at $-20{ }^{\circ} \mathrm{C}$.

Total RNA was extracted from the heart, liver, and kidney with TRIZOL ${ }^{\circ}$ Reagent (Invitrogen, San Diego, CA, USA), checked for concentration and purity using a NanoDrop 2000 Biophotometer (Thermo
Fisher Scientific Inc., West Palm Beach, FL, USA), and separated by electrophoresis in a $1 \%$ agarose gel to verify integrity. After treatment with DNase I, $2 \mu \mathrm{g}$ of RNA in a $20 \mu \mathrm{L}$ reaction volume was reversely transcribed into cDNA using a SuperRT cDNA Kit (CWBIO Ltd., Beijing, China).

Total protein was isolated from the heart, liver, and kidney using SDS Lysis Buffer (P0013B, Beyotime Ltd., China). Protein content was measured with the enhanced BCA protein assay kit (P0010, Beyotime, Ltd., China).

\section{SNP screening and genotyping}

Primers for identification of SNPs in the VEGFA gene (NM_214084) were based on DNA sequence obtained using the UCSC BLAT Search Genome tool (http://genome.ucsc.edu/). We used the amplified pig mRNA sequence and Primer Premier 5.0 software to design primers that amplified the coding regions (exons 1 to 7 ) and 5 -flanking sequences of the gene. The targeted regions, primer sequences, and amplicon sizes are shown in Table 1. PCR products amplified from 10 pigs in each group were pooled and sequenced to identify SNPs. Chromas Pro and DNAMAN6.0 were used to analyze the sequencing data. Genotypes of SNPs found by pooling sequencing were determined with individual PCR and sequencing.

\section{Quantitative analysis of VEGFA mRNA expression}

To avoid genomic DNA contamination, we used Primer Premier 5.0 software to design VEGFA gene (NM_214084) primers that amplified products spanning an intron. The primers were 5'-GAGGAGTTCAAC ATCGCCAT-3' and 5'-GAGGAGTTCAACATCGCCA3'. We used the housekeeping gene glyceraldehyde-3phosphate dehydrogenase (GAPDH, NM_001206359) as the internal standard and the primers were 5'-GGTCA CCAGGGCTGCTTTTA- $3^{\prime}$ and 5'-CCTTGACTGT GCCGTGGAAT-3'. Quantitative real-time PCR (qRT-

Table 1 Target region, sequence, and amplicon size of the primers used for SNP identification

\begin{tabular}{|c|c|c|c|c|}
\hline Primer & Target region & Forward primer sequence ( $5^{\prime}$ to $\left.3^{\prime}\right)$ & Reverse primer sequence $\left(5^{\prime}\right.$ to $\left.3^{\prime}\right)$ & Amplicon size, bp \\
\hline $5^{\prime}-\mathrm{FR} 1$ & $-1902 /-2693$ & AGTGACTGGCTCCTGTTCTC & CCTGGGTAGAAGTATTTGGC & 791 \\
\hline $5^{\prime}-F R 2$ & $-2193 /-1902$ & CGTTCCTTAGTGCTGGTGAG & AAAGTGAGGTTATGTGCGGC & 843 \\
\hline $5^{\prime}-\mathrm{FR3}$ & $-1546 /-631$ & GTGTGTCTGGGTGTGTGTGG & TCCCTCTCGTTCTTGCTTGC & 915 \\
\hline $5^{\prime}-\mathrm{FR} 4$ & $-654 /+53$ & GGGCAAGCAAGAAACGAGA & AGGTAGAGCAGCAAGGCAA & 707 \\
\hline VEGFA-P1 & Exon1 & GAGGAGGAAGAAGAGAAGGAAG & CATGTACGAGGATAGAGGGGAA & 472 \\
\hline VEGFA-P2 & Exon2 & CСATTCTTCCСTCTTTGTTITGTC & TTTGTITCCCAGTCTGTGCTCA & 367 \\
\hline VEGFA-P3 & Exon3 & GGCCGGCCCCCTCTACAG & AACGGGCTTITTAAACTCTCCACA & 630 \\
\hline VEGFA-P4 & Exon4-5 & CCTGGTCTGTGGAGAGTTAA & AGTGGGTAGAGAAAGAGAAA & 872 \\
\hline VEGFA-P5 & Exon6 & CTGCCGCTCTCTCTTGTCTTCTGC & AGCCACGCCTGCCACCTG & 564 \\
\hline VEGFA-P6 & Exon7 & CGTAGGGACTCTTCTITGGT & CTCGGCTTGTCACATCTGC & 313 \\
\hline
\end{tabular}


PCR) was conducted on the Bio-Rad CFX96 System (Bio-Rad, USA). Each reaction mixture contained $10.0 \mu \mathrm{L} 2 \times$ SYBR Green qPCR SuperMix (Transgen, Beijing, China), $1.0 \mu \mathrm{L}$ cDNA, $0.5 \mu \mathrm{L}$ of each primer $(10.0 \mathrm{nmol} / \mu \mathrm{L})$, and $\mathrm{ddH}_{2} \mathrm{O}$ water to adjust the volume to $20.0 \mu \mathrm{L}$. The real-time PCR program started with denaturation at $95{ }^{\circ} \mathrm{C}$ for $20 \mathrm{~s}$. This was followed by $40 \mathrm{cy}-$ cles of denaturation at $95{ }^{\circ} \mathrm{C}$ for $5 \mathrm{~s}$ and annealing/ elongation at $60{ }^{\circ} \mathrm{C}$ for $15 \mathrm{~s}$, during which fluorescence was measured. Next, a melting curve was constructed by increasing the temperature from $65{ }^{\circ} \mathrm{C}$ to $95{ }^{\circ} \mathrm{C}$ in sequential steps of $0.5{ }^{\circ} \mathrm{C}$ for $5 \mathrm{~s}$, during which fluorescence was measured. The real-time PCR efficiency of each pair of primers was calculated using 5 points in a 5 -fold dilution series of cDNA, which was used to construct a standard curve. A cDNA pool of all samples was used as a calibration and three replications of each sample were performed. Gene expression levels were calculated using the $2^{-\Delta \Delta \mathrm{Ct}}$ method $(\Delta \Delta \mathrm{Ct}=\Delta \mathrm{Ct}$ target gene -

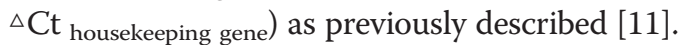

\section{Western blotting}

Approximately $30 \mathrm{mg}$ of each tissue used in quantitative real-time $\mathrm{PCR}$ was homogenized in lysis buffer $\left(10 \mathrm{mmol} / \mathrm{L} \mathrm{NaH}{ }_{2} \mathrm{PO}_{4}, 1 \mathrm{mmol} / \mathrm{L}\right.$ EDTA, $10 \mathrm{mmol} / \mathrm{L} \beta$ mercaptoethanol, $0.25 \%$ Triton X-100, and $0.02 \% \mathrm{NaN}_{3}$, adjusted to $\mathrm{pH}$ 6.8). Tissues were homogenized using a Mixer Mill MM400 (Retsch, Germany) for $5 \mathrm{~min}$ and then centrifuged at $10,000 \times g$ for $10 \mathrm{~min}$ at $4{ }^{\circ} \mathrm{C}$. Protein concentrations were determined using a Protein Assay Kit (Bio-Rad). Proteins $(40 \mu \mathrm{g})$ were separated by sodium dodecyl sulfate polyacrylamide gel electrophoresis (SDSPAGE) using a $5 \%$ stacking gel and a $10 \%$ separating gel. Following electrophoresis, proteins were transferred to Immobilon-P Transfer Membranes (IPVH00010) for $2 \mathrm{~h}$ at $300 \mathrm{~mA}$ using a Bio-Rad Criterion Blotter. Membranes were blocked overnight in blocking buffer (P0023B, Beyotime Ltd., China) and then incubated with primary mouse monoclonal GAPDH (1:1,000 dilution, AG019, Beyotime Ltd., China), and VEGFA (1:500 dilution, LS-C2929, LifeSpan BioSciences, Seattle, WA) antibodies diluted in primary antibody dilution buffer (P0023A, Beyotime Ltd., China) at $4{ }^{\circ} \mathrm{C}$ for $2 \mathrm{~h}$. After 3 washes with PBST(phosphate buffer saline containing $0.1 \%$ Tween 20), membranes were incubated with secondary HRP-labeled goat anti-mouse $\operatorname{IgG}(\mathrm{H}+\mathrm{L})$ (1:1,000 dilution, A0216, Beyotime Ltd., China) antibody diluted in secondary antibody dilution buffer (P0023D, Beyotime Ltd., China) for $1 \mathrm{~h}$. After the membranes were washed 3 times in Tris-buffered saline with Tween for $30 \mathrm{~min}$, immune complexes were visualized using an eECL Western Blot Kit (CW0049A, CWBIO Ltd., China) according to the manufacturer's instructions. To determine expression ratios of VEGFA and GAPDH, western blots were analyzed using Image J 1.44 software (NIH, USA).

\section{Cell culture}

Cell culture reagents were obtained from GIBCO (Life Technologies, Lofer, Austria). PIEC (KG302, KeyGEN BioTECH, China) were cultured according to the manufacturer's instructions. Experiments were performed using two incubators. For normoxia treatments, one incubator (Thermo Fisher Scientific Inc., West Palm Beach, FL, USA) was set at $37{ }^{\circ} \mathrm{C}$ and $5 \% \mathrm{CO}_{2}$; the incubator oxygen sensor indicated approximately $21 \% \mathrm{O}_{2}$. Cells were cultured under normoxic conditions for 2,4 , $8,12,24$, or 36 h. For hypoxia treatments, an incubator (3 gas incubator, Changsha Hua Xi Electronics Technetronic Co., Ltd., China) was set at $37{ }^{\circ} \mathrm{C}, 5 \% \mathrm{CO}_{2}$, and $94 \% \mathrm{~N}_{2}$; the oxygen sensor indicated approximately $1 \%$ $\mathrm{O}_{2}$. Cells were cultured under hypoxic conditions for 2, $4,8,12,24$, or $36 \mathrm{~h}$. Cells were collected after the indicated durations in culture and total RNA extraction, cDNA synthesis and qTR-PCR were performed as described above.

\section{Statistical analyses}

Expression levels were analyzed by one-way ANOVA using SAS9.1 Software (SAS Inst. Inc., Cary, NC). Graphs were prepared using SigmaPlot 10.0 (Systat Software, San Jose, CA) and data are presented as mean \pm standard error. Significant and extreme differences were set at $P<0.05(*)$ and $P<0.01(* *)$, respectively.

\section{Results}

\section{SNPs and genotype frequencies}

The structure of the pig VEGFA gene and the positions of the primers used for SNP identification are shown in Fig. 1. Using the primers listed in Table 1, the PCR amplicons covered 2,693 bp of the 5 -flanking and fullcoding regions (all 7 exons). No SNPs were detected in the coding region of the VEGFA gene among the TP, YL, and DN populations. Sanger sequencing revealed 5 SNPs at upstream 2,435,2,442, 2,745, 1,010, and 1,773 bp from the initiation codon of the VEGFA gene that were named G-2745C, G-2442A, G-2435deletion, T-1010C and C-1773 $\mathrm{T}$ respectively (Fig. 2).

Individual sequencing analysis indicated genotype and allele frequencies of the 5 SNPs in the 3 pig populations (Table 2). No significant differences in genotypes distributions at loci G-2745C, G-2442A, and G-2435deletion were seen comparing TP with YL or DN $(P>0.05)$. Although the TP had a different genotype distribution in $\mathrm{T}-1010 \mathrm{C}$ with the DN, the difference between TP and YL was not significant $(P>0.05)$. At locus $\mathrm{C}-1773 \mathrm{~T}$, there were significant differences in genotype frequency 


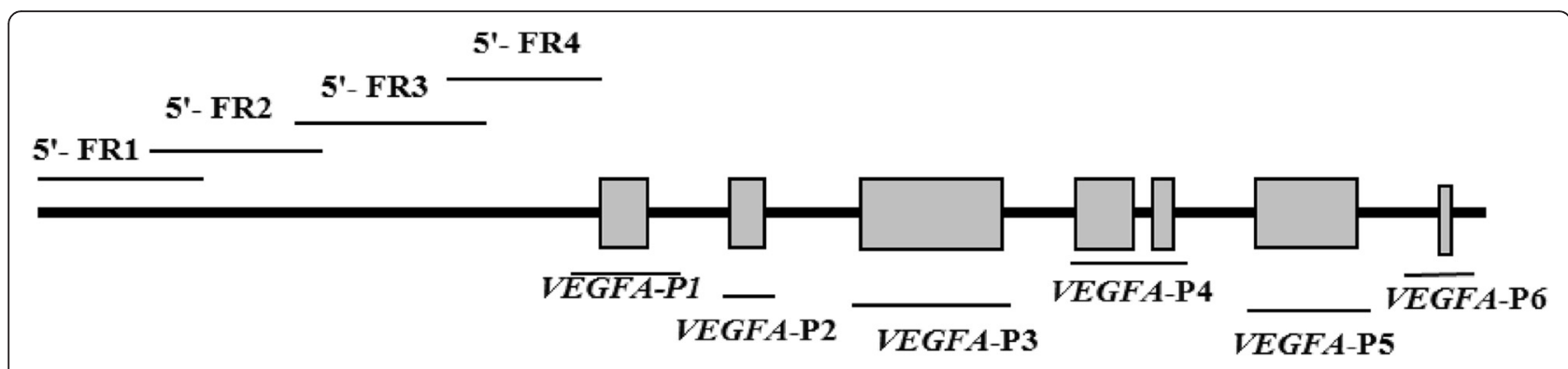

Fig. 1 Structure of the pig VEGFA gene and the positions of primers used for SNP identification. The thick black lines represent flanking regions and introns; the grey blocks represent exons of the VEGFA gene; the thin black lines represent positions of amplicons. Pig total DNA was used as PCR templates for the 5'-FR1, 5'-FR2, 5'-FR3, 5'-FR4, VEGFA-P1, VEGFA-P2, VEGFA-P3, VEGFA-P4, and VEGFA-P5 primers

comparing TP with YL or DN; however, the allele C frequency of TP was between YL and DN.

\section{VEGFA mRNA expression}

PCR efficiencies of VEGFA and GAPDH genes were within 95 to $105 \%$ that was satisfied for qRT-PCR. Expression of VEGFA mRNA is shown in Fig. 3. We found that expression of VEGFA mRNA was relatively high in the liver and kidney, but low in the heart. Moreover, under hypoxic conditions, expression of VEGFA mRNA in all three tissues was significantly higher in TP than in $\mathrm{YH}$ and YL $(P<0.01)$. Following migration of Yorkshire pigs from lowland to highland, expression of VEGFA mRNA increased in the kidney $(P<0.05)$, but trended downward in the liver.

\section{VEGFA protein expression}

Results western blot showed that the VEGFA protein expression had same difference trends in heart, liver and kidney with mRNA expression between the three groups (Fig. 4). The protein expression was significantly higher in heart and liver of TP than that of $\mathrm{YH}$ and YL $(P<0.05)$. While in kidney tissue, the TP had higher VEGFA protein expression than YL $(P<0.05)$ and $\mathrm{YH}$, although the difference between TP and $\mathrm{YH}$ was not significant $(P>0.05)$.

\section{VEGFA gene expression in PIEC cells}

Expression of VEGFA mRNA in endothelial cells is shown in Fig. 5. At all time points, expression of VEGFA mRNA in vitro was higher under hypoxic condition than

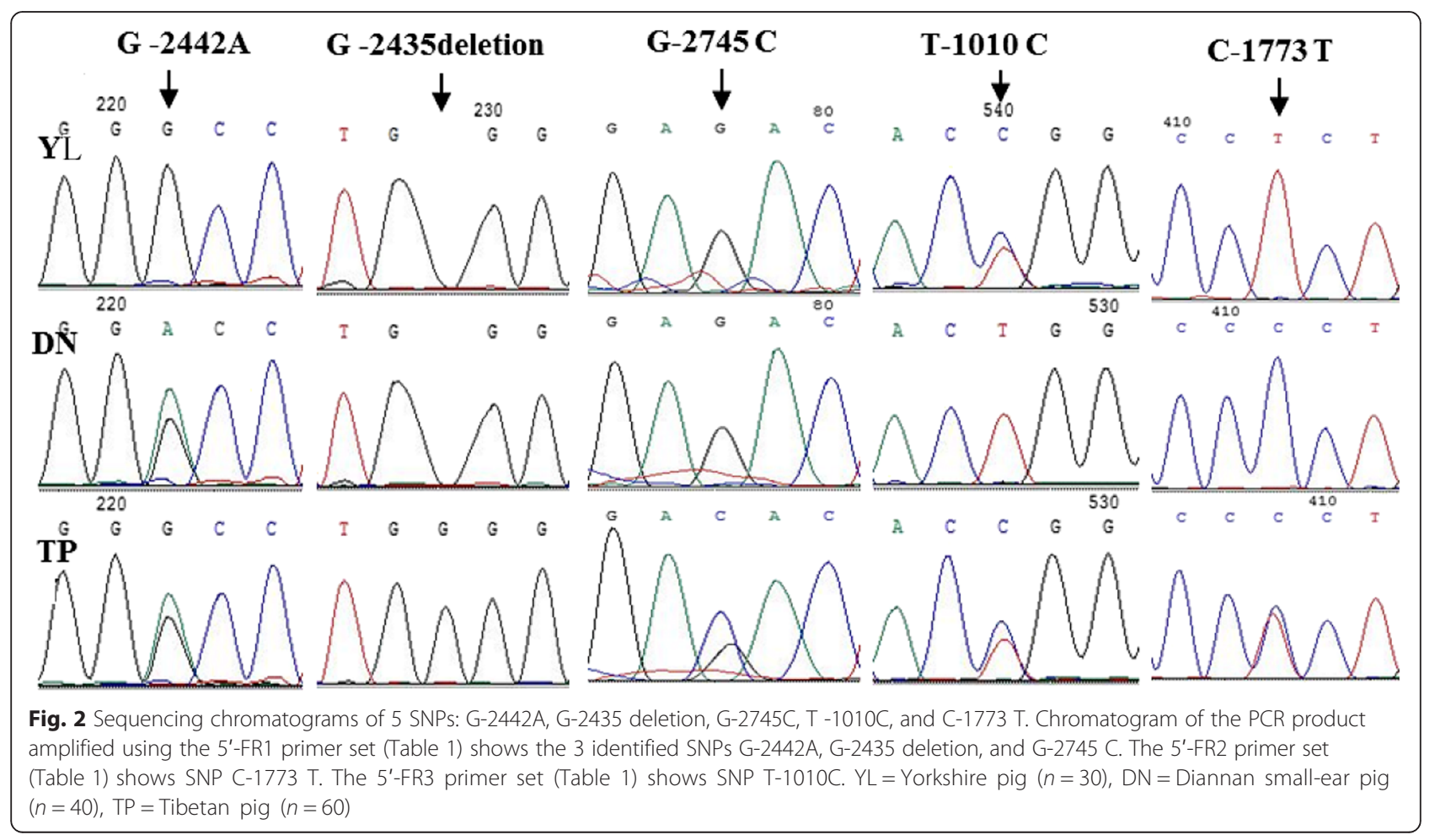


Table 2 Gene and genotype frequency of the 5 SNPs in different pig breeds

\begin{tabular}{|c|c|c|c|c|c|c|c|}
\hline \multirow[t]{2}{*}{ Loci } & \multirow[t]{2}{*}{ Breed } & \multicolumn{4}{|c|}{ Genotype (number/percentage) } & \multicolumn{2}{|l|}{ Allele } \\
\hline & & GG & GC & CC & $P$ value* (Fisher's exact test) & G & C \\
\hline \multirow[t]{4}{*}{ G-2745C } & $Y L$ & $10 / 1$ & 0/0 & 0/0 & 0.237 & 1 & 0 \\
\hline & DN & $10 / 1$ & $0 / 0$ & $0 / 0$ & 0.237 & 1 & 0 \\
\hline & TP & $8 / 0.800$ & $2 / 0.200$ & 0/0 & & 0.900 & 0.100 \\
\hline & & GG & GA & AA & & G & A \\
\hline \multirow[t]{4}{*}{ G-2442A } & $Y L$ & $10 / 1$ & $0 / 0$ & 0/0 & 0.500 & 1 & 0 \\
\hline & DN & $9 / 0.900$ & $1 / 0.1$ & $0 / 0$ & 0.763 & 0.950 & 0.050 \\
\hline & TP & $9 / 0.900$ & $1 / 0.1$ & 0/0 & & 0.950 & 0.050 \\
\hline & & GG & G-deletion & Deletion & & G & Deletion \\
\hline \multirow[t]{4}{*}{ G-2435 deletion } & $Y L$ & $8 / 0.889$ & $1 / 0.111$ & $0 / 0$ & 0.474 & 0.940 & 0.060 \\
\hline & DN & $7 / 0.700$ & 0/0 & $3 / 0.300$ & 0.105 & 0.700 & 0.300 \\
\hline & TP & $10 / 1$ & 0/0 & 0/0 & & 1 & 0 \\
\hline & & $\pi$ & $\mathrm{TC}$ & CC & & $\mathrm{T}$ & $C$ \\
\hline \multirow[t]{4}{*}{ T-1010C } & $Y L$ & $35 / 0.875$ & $5 / 0.125$ & 0/0 & 0.342 & 0.938 & 0.062 \\
\hline & DN & $40 / 1$ & 0/0 & 0/0 & 0.010 & 1 & 0 \\
\hline & TP & $16 / 0.8$ & $4 / 0.2$ & 0/0 & & 0.900 & 0.100 \\
\hline & & CC & $C T$ & $\pi$ & & $C$ & $\mathrm{~T}$ \\
\hline \multirow[t]{3}{*}{ C-1773 T } & $Y L$ & $1 / 0.034$ & $7 / 0.233$ & $22 / 0.733$ & 0.000 & 0.150 & 0.850 \\
\hline & DN & $36 / 1$ & 0/0 & 0/0 & 0.001 & 1 & 0 \\
\hline & TP & $14 / / 0.700$ & $4 / 0.200$ & $2 / 0.100$ & & 0.800 & 0.200 \\
\hline
\end{tabular}

Note: *P value was significance of the exact test for genotype frequency distribution compared with TP. YL $=$ Yorkshire pig $(n=30)$, DN $=$ Diannan small-ear pig $(n=40), \mathrm{TP}=$ Tibetan pig $(n=60)$

under normoxic condition $(P<0.05)$. Under both normoxic and hypoxic conditions, expression of VEGFA mRNA had an increased trend after 4 h over time.

\section{Discussion}

$V E G F A$ is a pivotal angiogenic factor that binds to specialized receptors on the surface of endothelial cells and induces them to generate new vessels [12]. VEGFA expression was modulated by HIF-1 through binding to promoters of hypoxia response elements (HREs) [13, 14].

We found 5 SNPs in the VEGFA gene. TP, as well as the other pig breeds, exhibited relatively large polymorphisms at the 5 loci, although the distinction between frequency distributions was not significant. No SNPs were detected in the coding region of the VEGFA gene. The mRNA sequence of VEGFA was highly conserved among pig breeds, which is consistent with previous
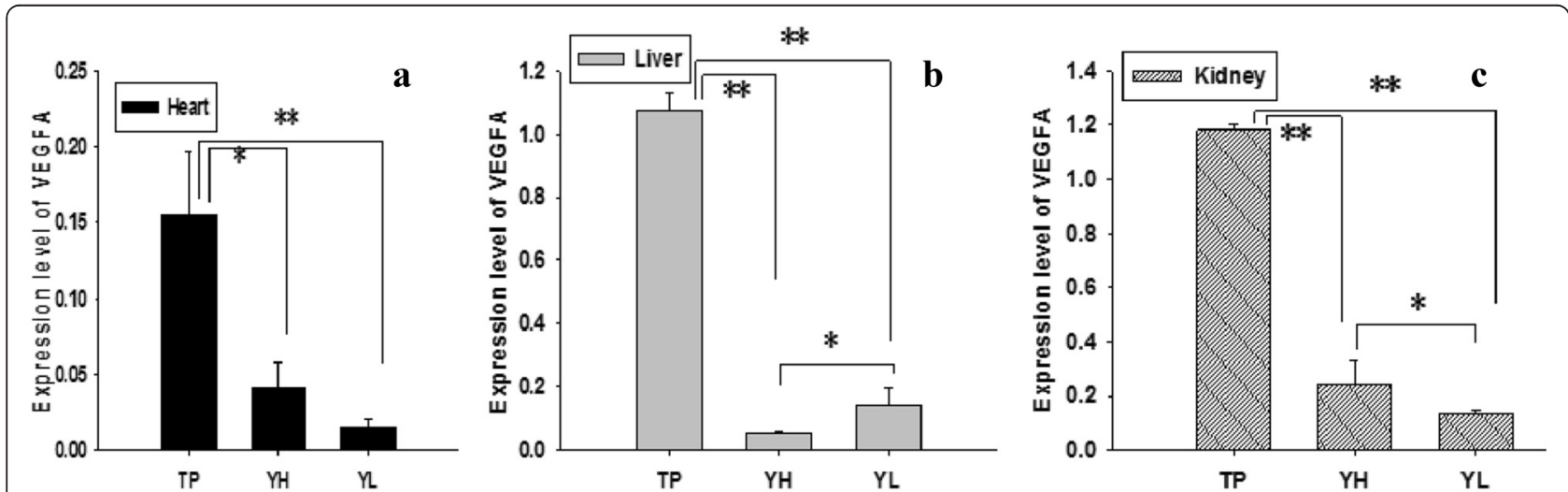

Fig. 3 Expression of VEGFA mRNA in the heart $(\mathbf{a})$, liver $(\mathbf{b})$, and kidney $(\mathbf{c})$. Each bar represents mean \pm S.E. $*$ Significant difference $(P<0.05)$, ** Extreme significant difference $(P<0.01)$. TP = Tibetan pig $(n=10)$; YH = Yorkshire pig raised at high-altitude $(n=10)$; YL=Yorkshire pig raised at lowland $(n=10)$ 


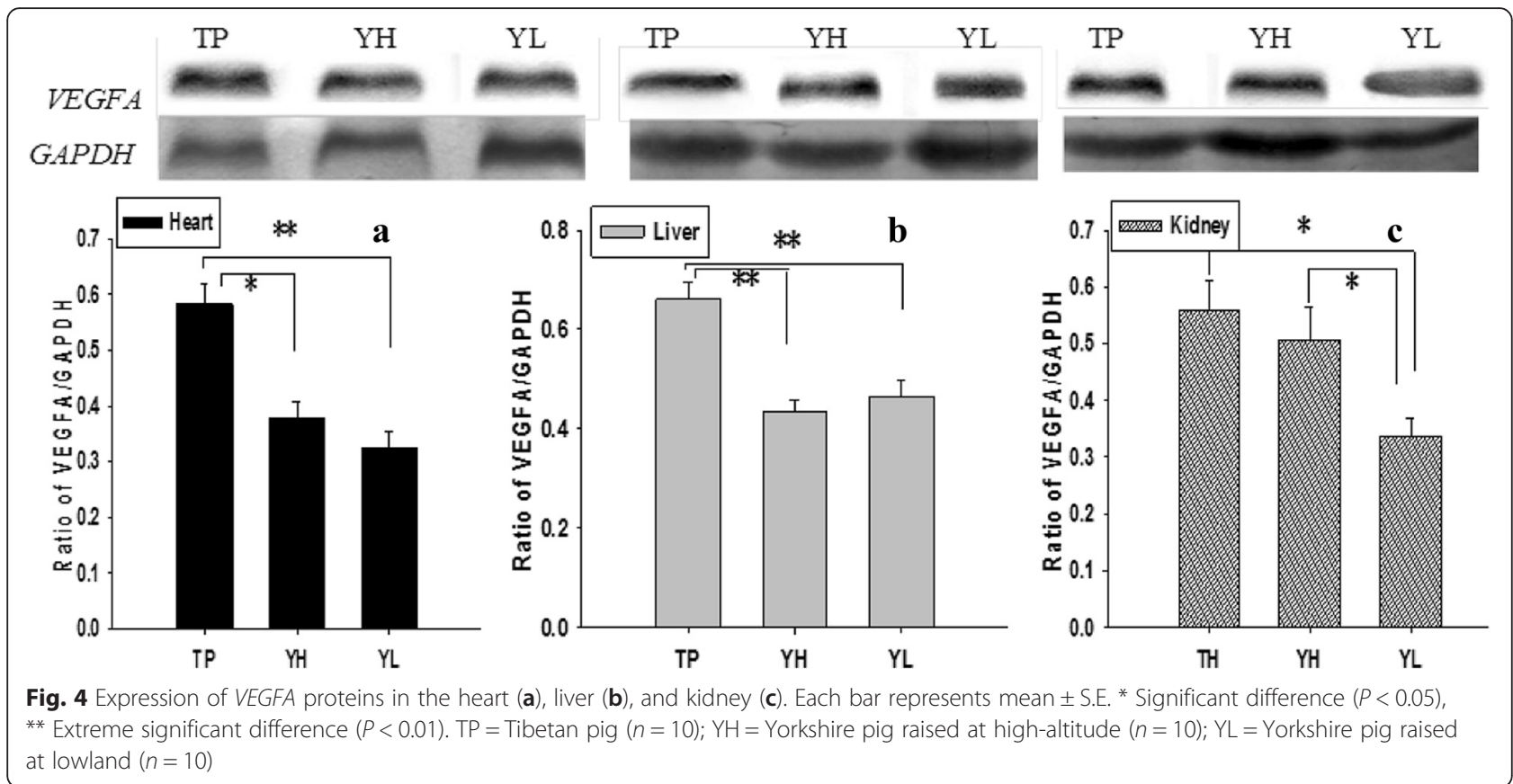

studies showing that both the mRNA sequence and protein domain of human VEGFA gene were conserved [15]. Thus, the biological function of VEGFA is primarily regulated by controlling its expression. The results also indicated that there might be other regulatory mechanisms (for example of epigenetic regulation) in the region or functional SNPs in long-distance regions. It was a pending work what SNPs or what other regulatory mechanisms could regulate the gene expression and have roles on hypoxic adaptation in Tibetan pig.

The heart plays an important role in adaptation to hypoxia. It has been reported that decreased cardiac VEGFA signaling interferes with myocardial angiogenesis. This results in local ischemia, which triggers cardiomyocyte damage and heart failure $[16,17]$. In the present study, VEGFA expression in heart tissue was significantly higher in TP compared with Yorkshire under hypoxia at high altitudes. To adapt to a hypoxic environment, TP increased expression of the VEGFA gene in vivo and changed their cardiovascular response to hypoxia. The increased VEGFA expression might increase blood flow and enhance cardiac pumping $[18,19]$.

In the early phase of liver regeneration, proliferating hepatocytes showed hypoxia-induced VEGFA expression,

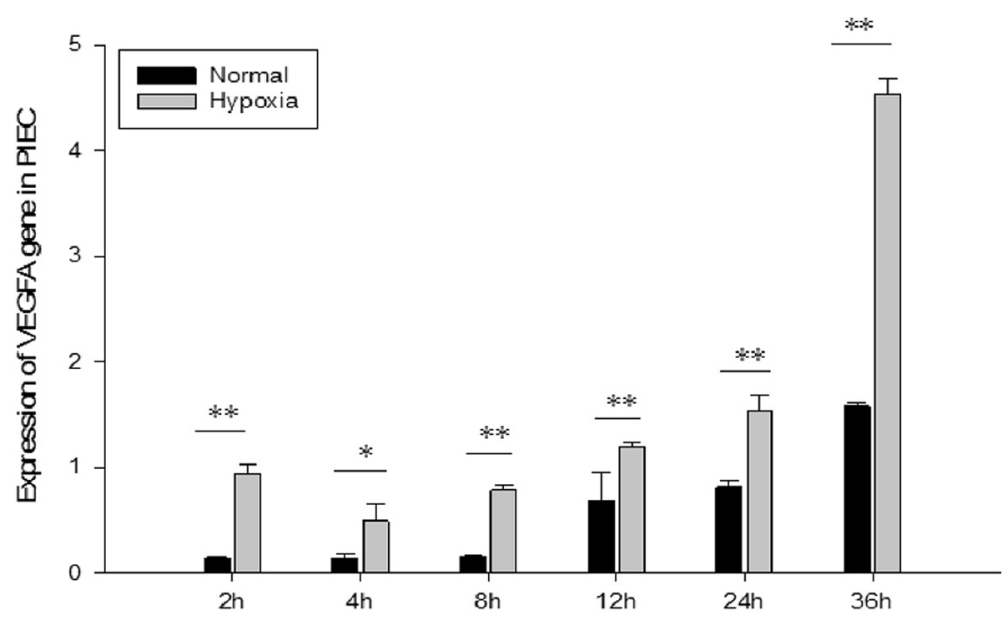

Fig. 5 Quantitative expression of VEGFA mRNA in endothelial cells. Each bar represents mean \pm S.E. * Significant difference $(P<0.05)$, ** Extreme significant difference $(P<0.01)(n=3)$ 
which initiates proper blood flow through the liver [20]. Our results consistently showed that expressions of VEGFA mRNA and protein in liver were significantly higher in TP than in $\mathrm{YH}$ and $\mathrm{YL}$, which indicated that the TP might improve blood flow in liver tissue to adapt to hypoxia.

VEGFA plays a crucial role in the kidney, where it is produced primarily by glomerular epithelial cells (podocytes) and is also found in epithelial cells [21, 22]. In mice, specific overexpression or deletion of the VEGFA gene in podocytes results in glomerular dysfunction [23, 24]. Moreover, VEGFA acts as an autocrine growth factor on both proliferating and differentiating glomerular visceral epithelial cells (podocytes) [24] and has roles in prolonged survival and resistance to apoptosis [25]. In the present study, TP showed a high expression level of the VEGFA gene, suggesting that VEGFA plays a pivotal role in the maintenance of glomerular integrity under hypoxia in the kidneys of pigs.

\section{Conclusion}

We found that the mRNA sequence of the pig VEGFA gene was conserved among pig breeds, which indicated the biological function of the gene was primarily regulated by differential expression. Only five SNPs (G-2745C, G-2442A, G-2435deletion, C-1773 T and $\mathrm{T}-1010 \mathrm{C}$ ) were found in the $5^{\prime}$-flanking region of length of $2693 \mathrm{bp}$ upstream from the initiation codon of the VEGFA gene among the TP, YL, and DN populations. However, further studies are required to identify the site that can regulate the gene expression in pig. The Tibetan pig had considerably high expressions of the VEGFA gene in heart and liver tissues in high-altitude environment. The increased VEGFA expression might be one way of genetic adaptation to hypoxia in high-altitude, through promoting endothelial cells proliferation, angiogenesis and maintaining vascular permeability. Further research on molecular mechanisms of the VEGFA for hypoxic adaptation was a pending work in Tibetan pig.

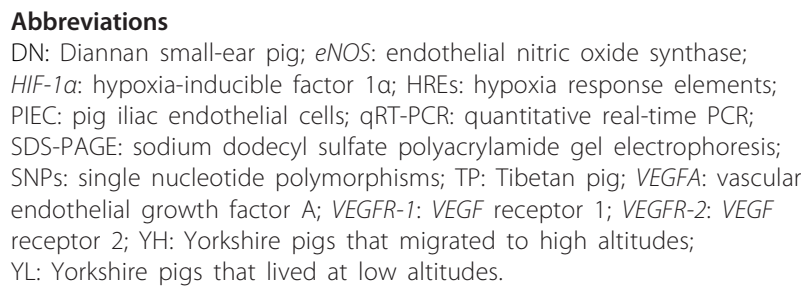

\section{Competing interests}

The authors declare that they have no competing interests.

\section{Authors' contributions}

$\mathrm{HZ}$ provided essential experiment conditions and instruments. $\mathrm{HZ}, \mathrm{YZQB}$ and $B Z$ conceived and designed the experimental plan. BZ, PS, YFL, YZY and ZXW participated in collecting tissues. BZ and YZQB performed the molecular experiment. PS and YFL analysed the data and interpreted the results. BZ drafted this manuscript. All authors critically revised the manuscript for important intellectual contents and approved the final manuscript.

\section{Acknowledgments}

This work was supported by the National Major Special Project on New Varieties Cultivation for Transgenic Organisms (2016ZX08009-003-006) and the National Key Technology R\&D Program (2012BAD03B03) and the Program for Changjiang Scholar and Innovation Research Team in University (IRT1191).

\section{Author details}

${ }^{1}$ National Engineering Laboratory for Animal Breeding, China Agricultural University, Beijing 100193, People's Republic of China. ${ }^{2}$ College of Agriculture and Animal Husbandry, Tibet University, Linzhi 860000, People's Republic of China. ${ }^{3}$ School of life science \& technology, Nanyang normal University, Nanyang 473061, Henan Province, People's Republic of China. ${ }^{4}$ Hebei Provincial Husbandry and Veterinary Research Institute, Baoding, Hebei 071001, People's Republic of China.

Received: 12 August 2015 Accepted: 22 March 2016

Published online: 02 April 2016

\section{References}

1. Gille H, Kowalski J, Li B, LeCouter J, Moffat B, Zioncheck TF, et al. Analysis of biological effects and signaling properties of Flt-1 (VEGFR-1) and KDR (VEGFR-2) A reassessment using novel receptor-specific vascular endothelial growth factor mutants. J Biol Chem. 2001;276:3222-30.

2. Matsumoto T, Mugishima H. Signal transduction via vascular endothelial growth factor (VEGF) receptors and their roles in atherogenesis. J Atheroscler Thromb. 2006;13:130-5

3. Lohela M, Bry M, Tammela T, Alitalo K. VEGFs and receptors involved in angiogenesis versus lymphangiogenesis. Curr Opin Cell Biol. 2009;21:154-65.

4. Carmeliet P, Moons L, Luttun A, Vincenti V, Compernolle V, De Mol M, et al. Synergism between vascular endothelial growth factor and placental growth factor contributes to angiogenesis and plasma extravasation in pathological conditions. Nat Med. 2001;7:575-83.

5. Geiger R, Berger RM, Hess J, Bogers AJ, Sharma HS, Mooi WJ. Enhanced expression of vascular endothelial growth factor in pulmonary plexogenic arteriopathy due to congenital heart disease. J Pathol. 2000;191:202-7.

6. Hirose S, Hosoda Y, Furuya S, Otsuki T, Ikeda E. Expression of vascular endothelial growth factor and its receptors correlates closely with formation of the plexiform lesion in human pulmonary hypertension. Pathol Int. 2000; 50:472-9.

7. Cheng P. Livestock breeds of China. Food and Agriculture Organization of the United Nations. 1985.

8. Pan PW, Zhao SH, Yu M, Liu B, Xiong TA, Li K. Identification of differentially expressed genes in the Longissimus Dorsi muscle tissue between Duroc and Erhualian pig by mRNA differential display. Asian Aust J Anim. 2003;16: 1066-70.

9. Gong JJ, He ZP, Li ZQ, Lv XB, Ying SC, Chen XH. Investigation on fattening and carcass traits in Tibetan pig and its combinations. Southwest China J Agric Sci. 2007;20:1109-12.

10. Green MR, Sambrook J. Molecular cloning: a laboratory manual. New York: Cold Spring Harbor Laboratory Press; 2012.

11. Livak KJ, Schmittgen TD. Analysis of relative gene expression data using real-time quantitative PCR and the $2^{-\Delta \Delta C}$ method. Methods. 2001;25:402-8.

12. Goodsell DS. The molecular perspective: VEGF and angiogenesis. Stem Cells. 2003;21:118-9.

13. Semenza GL. Regulation of mammalian $\mathrm{O} 2$ homeostasis by hypoxia-inducible factor 1. Annu Rev Cell Dev Bi. 1999;15:551-78.

14. Kim HA, Lim S, Moon H, Kim SW, Hwang K, Lee M, et al. Hypoxia-inducible vascular endothelial growth factor gene therapy using the oxygendependent degradation domain in myocardial ischemia. Pharm Res Dordr. 2010;27:2075-84

15. Golozar A, Beaty TH, Gravitt PE, Ruczinski I, Qiao Y, Fan J, et al. Oesophageal squamous cell carcinoma in high-risk Chinese populations: Possible role for vascular epithelial growth factor A. Eur J Cancer. 2014;50:2855-65. 
16. Shiojima I, Sato K, Izumiya Y, Schiekofer S, Ito M, Liao R, et al. Disruption of coordinated cardiac hypertrophy and angiogenesis contributes to the transition to heart failure. J Clin Invest. 2005;115:2108.

17. Taimeh Z, Loughran J, Birks EJ, Bolli R. Vascular endothelial growth factor in heart failure. Nat Rev Cardiol. 2013;10:519-30.

18. Chiu CL, Morgan CT, Lupton SJ, Lind JM. Parent of origin influences the cardiac expression of vascular endothelial growth factor (VEGFA). BMC Med Genet. 2013;14:43.

19. Cor AD, Astanina E, Giraudo E, Bussolino F. Semaphorins in cardiovascular medicine. Trends Mol Med. 2014;20:589-98.

20. Kajdaniuk D, Marek B, Borgiel-Marek H, Kos-Kud LAB. Vascular endothelial growth factor (VEGF) - part 1: in physiology and pathophysiology. Endokrynol Pol. 2011;62:444-55.

21. Robert B, Zhao X, Abrahamson DR. Coexpression of neuropilin-1, Flk1, and $V_{E G F} 164$ in developing and mature mouse kidney glomeruli. Am J Physiol Renal. 2000;279:F275-82.

22. Baderca F, Lighezan R, Dema A, Alexa A, Raica M. Immunohistochemical expression of VEGF in normal human renal parenchyma. Rom J Morphol Embryol. 2006;47:315-22.

23. Eremina V, Sood M, Haigh J, Nagy AAS, Lajoie G, Ferrara N, et al. Glomerular-specific alterations of VEGF-A expression lead to distinct congenital and acquired renal diseases. J Clin Invest. 2003:111:707.

24. Eremina V, Quaggin SE. The role of VEGF-A in glomerular development and function. Curr Opin Nephrol Hypertens. 2004;13:9-15.

25. Foster RR, Hole R, Anderson K, Satchell SC, Coward RJ, Mathieson PW, et al. Functional evidence that vascular endothelial growth factor may act as an autocrine factor on human podocytes. Am J Physiol Renal. 2003;284:F1263-73.

Submit your next manuscript to BioMed Central and we will help you at every step:

- We accept pre-submission inquiries

- Our selector tool helps you to find the most relevant journal

- We provide round the clock customer support

- Convenient online submission

- Thorough peer review

- Inclusion in PubMed and all major indexing services

- Maximum visibility for your research

Submit your manuscript at www.biomedcentral.com/submit
Biomed Central 